\title{
EFFECT OF THE FORM AND CONCENTRATION OF N ON THE GROWTH AND MINERAL COMPOSITION OF OLIVE SEEDLINGS
}

\author{
R. Sarmiento, J.L.. García, C. Mazuelos, J. Liñán, and A. Troncoso \\ Instituto de Recursos Naturales y Agrobiología de Sevilla (IRNAS) CSIC. P.O. Box \\ 1052, 41080 Sevilla Spain.
}

Key words: olive, embryos, seedlings, in vitro, nitrogen, nutrition, growth

$\underline{\text { Abstract }}$

The influence of three salts $\left(\mathrm{KNO}_{3}, \mathrm{NH}_{4} \mathrm{NO}_{3}\right.$ and $\left.\left(\mathrm{NH}_{4}\right)_{2} \mathrm{SO}_{4}\right)$ in different concentrations, on the growth and mineral composition of olive seedlings cultured in vitro and in greenhouse conditions, was studied.

The best growth was obtained in in vitro culture through the applications of $\mathrm{NH}_{4} \mathrm{NO}_{3}$, in concentrations of 10 and $20 \mathrm{mM}$ of $\mathrm{N}$. Addition of $\left(\mathrm{NH}_{4}\right)_{2} \mathrm{SO}_{4}$ clearly damaged the seedlings and increased the contents of $\mathrm{S}$ in the seedlings' tissues. All the treatments led to a direct relationship between concentration of $\mathrm{N}$ in the medium and $\mathrm{N}$ in the seedling tissues, however the $\mathrm{N}$-increases were lowest for $\mathrm{KNO}_{3}$ and highest for ammonium applications, especially for $\mathrm{NH}_{4} \mathrm{NO}_{3}$.

In greenhouse conditions all the $\mathrm{N}$-treatments significantly increased the growth of the seedlings but no significant differences between $\mathrm{N}$-salts were observed except for $\left(\mathrm{NH}_{4}\right)_{2} \mathrm{SO}_{4}$ at the highest concentration. Treatment with $\left(\mathrm{NH}_{4}\right)_{2} \mathrm{SO}_{4}$ did not induce any symptom of toxicity in the seedlings, in contrast to the behaviour of in vitro seedlings. The treatments did not cause significant changes in the mineral composition of the seedling tissues. These circumstances were related to the fact that an oxidation process (nitrification) was produced from $\mathrm{N}-\mathrm{NH}_{4}$ to $\mathrm{N}-\mathrm{NO}_{3}$ in the nutritive solutions in the containers.

\section{Introduction}

Due to lack of satisfactory olive cultivars for modern intensive orchards, there is increasing interest in carrying out serious genetic improvement programs. Nevertheless, the long juvenile phase of olive seedlings, which sometimes exceeds 10 years, has discouraged many research projects.

Hackett (1985) defined the juvenile phase as the physiological period of a seedling when there is no possibility of flowering. García-Berenguer (1991) carried out a review of the factors related to the change of phase (juvenile-adult) and remarked that in order to undergo the change the seedling needs to reach minimum development. Lavee (unpublished dates) found ways of shortening the juvenile period of olive seedlings, training single shoot upright plants together with controlled thinning and shortening of the lateral juvenile branches and intensive growing conditions.

Nutritional factors, especially nitrogen, have considerable influence on the growth of young olive plant in greenhouse conditions (Bartolini et al., 1984; Troncoso et al., 1986). Nitrogen also has a considerable influence on the growth of in vitro plant material (Hagin et al., 1990; Troncoso et al., 1990 and Sarmiento et al., 1992), however there are no references to olive plant in this culture system.

The aim of this work was to contribute to a better knowledge of nitrogen (forms and concentrations) effects on the growth and mineral composition of young olive seedlings (from olive embryos) cultured in vitro and in greenhouse conditions during early growth. We endeavoured to obtain better initial plants to contribute to shortening the juvenile phase and to understand the N-metabolism. 


\section{Material and methods}

Seeds from olive fruits (cv. manzanilla) harvested in September from a single, isolated tree, were used as plant material. The hard endocarp of the seed was eliminated (Sotomayor and Caballero, 1989) and the soft part treated with ethanol $75 \%$ (3 min.), commercial bleach $10 \%$ (10 min.) and washed with sterilized water. They were incubated in sterilized water for $48 \mathrm{~h}$. at $25, \mathrm{C}$, to promote swelling in order to facilitate the embryo extraction, which was done by cutting the endosperm with a scalpel, two lateral sections, and taking out the embryo with the edge of the scalpel from the central one.

The olive embryos were cultured in vitro at $25, \mathrm{C}$, with $16 \mathrm{~h}$. of photoperiod and 30 EE.m-2.s-1 of light intensity, for 60 days. The following culture media were used: Control (A)-OM medium (Rugini, 1984) half-strength without any nitrogen; Control (B)-OM medium (Rugini, 1984) half-strength; 9 nitrogen treatments, adding to Control (A) respectively $3 \mathrm{~N}$-salts $\left(\mathrm{KNO}_{3}, \mathrm{NH}_{4} \mathrm{NO}_{3}\right.$ and $\left.\left(\mathrm{NH}_{4}\right)_{2} \mathrm{SO}_{4}\right)$ at 3 concentrations $(5,10$ and $20 \mathrm{mM}$ of $\mathrm{N}$ ). In total 880 olive embryos were used (40 per treatment, 11 treatments and 2 experiments).

For the greenhouse experiment, in vitro olive seedlings were used. They were divided into 10 homogeneous groups of 10 plants (treatments) growing in pots of $3 \mathrm{~kg}$ of inert sand and treated (using drip irrigation system) with nutritive solution of Hoagland $20 \%$ strength with only $\mathrm{Ca}\left(\mathrm{NO}_{3}\right)_{2}$ as source of $\mathrm{N}$ (basal solution and control) and 9 $\mathrm{N}$-treatments, respectively, adding $3 \mathrm{~N}$-salts $\left(\mathrm{KNO}_{3}, \mathrm{NH}_{4} \mathrm{NO}_{3}\right.$ and $\left.\left(\mathrm{NH}_{4}\right)_{2} \mathrm{SO}_{4}\right)$ to the basal solution at 3 concentrations $(2,3$ and $4 \mathrm{mM}$ of $\mathrm{N})$ respectively. The nutritive solutions were kept in pvc containers protected from the sunlight and were renewed every 2 months.

After 60 days in the in vitro experiments and every month for 6 months in the greenhouse experiment, the growth of the seedlings was measured, and after each experiment the mineral composition (Pinta et al., 1973) of each group of seedlings was determined. During the greenhouse experiment the evolution of the concentrations of $\mathrm{N}-\mathrm{NO}_{3}$ and $\mathrm{N}-\mathrm{NH}_{4}$ of the nutritive solutions was also checked (Bremmer and Keeney, 1966; Keeney and Nelson, 1982).

\section{Results and discussion}

Through daily observations of the in vitro seedlings it was established that $\mathrm{N}$-additions, mainly $\mathrm{NH}_{4} \mathrm{NO}_{3}$, with the exception of $\left(\mathrm{NH}_{4}\right)_{2} \mathrm{SO}_{4}$, increased the speed of the embryo development, the opening and green coloration of the cotyledons, and leaves and roots formation. The length (mean and max.) reached by each group (treatment) of embryos, after 60 days of in vitro culture, (figure 1) showed that, in general, $\mathrm{N}$-applications increased the size of the seedlings, specially $\mathrm{NH}_{4} \mathrm{NO}_{3}$ at 10 and $20 \mathrm{mM}$ of $\mathrm{N}$. Additions of $\left(\mathrm{NH}_{4}\right)_{2} \mathrm{SO}_{4}$, in direct relation to the salt concentration, clearly damaged the seedlings, delaying and decreasing their growth and causing the death of some of them. This indicated a low tolerance of olive embryo to the latter salt.

The $\mathrm{N}$-treatments also influenced the mineral composition of the seedlings (table 1).

All the treatments led to a direct relationship between concentration of $\mathrm{N}$ in the medium and in the seedling tissues, but at different levels depending on the $\mathrm{N}$-salt used. The $\mathrm{N}$ levels and increases, were lowest for $\mathrm{KNO}_{3}$ and highest for ammonium applications, especially for $\mathrm{NH}_{4} \mathrm{NO}_{3}$ at 10 and $20 \mathrm{mM}$ of $\mathrm{N}$. These results were in agreement with Hagin et al's. review (1990) and with data obtained by Troncoso et al. (1990) and Sarmiento et al. (1992) from grape vine explants, and were probably related to the high energy requirement for reduction by nitrate reductase and subsequent assimilation of N-NO 3 (Stewart and Rhodes, 1977; Campbell, 1988). K contents were also affected by the treatments. $\mathrm{KNO}_{3}$ additions increased the $\mathrm{K}$-contents (direct relationship between $\mathrm{K}$-medium añd K-tissues) and also favoured the absorption of other cations as $\mathrm{Ca}$ and 
Mg. $\mathrm{NH}_{4} \mathrm{NO}_{3}$ additions also increased the contents of $\mathrm{K}, \mathrm{Ca}$ and $\mathrm{Mg}$ in relation to the control, but less than $\mathrm{KNO}_{3} . \mathrm{K}$ and $\mathrm{N}_{-} \mathrm{NO}_{3}$ seemed to have a favourable effect on the absorption of $\mathrm{K}, \mathrm{Ca}$ and $\mathrm{Mg}$. On the other hand, the additions of $\left(\mathrm{NH}_{4}\right)_{2} \mathrm{SO}_{4}$ led to a decrease of $\mathrm{K}$ in the tissues. In comparison with control seedlings there was an increase of $S$-contents (in direct relationship to the salt concentration) in the seedlings treated with $\left(\mathrm{NH}_{4}\right)_{2} \mathrm{SO}_{4}$.

Table 1. Influence of $\mathrm{N}$ on the level of the affected nutrients of olive seedlings in vitro.

\begin{tabular}{lrrrrrr}
\hline & & \multicolumn{5}{c}{ Content of nutrient (\% DW) } \\
\cline { 3 - 7 } Treatment & & $\mathrm{N}$ & $\mathrm{K}$ & $\mathrm{Ca}$ & $\mathrm{Mg}$ & $\mathrm{S}$ \\
\hline Control & $(\mathrm{A})$ & 2.43 & 1.29 & 0.19 & 0.18 & 0.12 \\
$\mathrm{KNO}_{3}$ & $(5)$ & 3.23 & 3.03 & 0.33 & 0.37 & - \\
$\mathrm{KNO}_{3}$ & $(10)$ & 3.00 & 3.20 & 0.31 & 0.34 & - \\
$\mathrm{KNO}_{3}$ & $(20)$ & 3.34 & 4.32 & 0.27 & 0.35 & - \\
$\mathrm{NH}_{4} \mathrm{NO}_{3}$ & $(5)$ & 3.55 & 2.70 & 0.23 & 0.23 & - \\
$\mathrm{NH}_{4} \mathrm{NO}_{3}$ & $(10)$ & 4.40 & 2.54 & 0.22 & 0.22 & - \\
$\mathrm{NH}_{4} \mathrm{NO}_{3}$ & $(20)$ & 4.67 & 1.65 & 0.26 & 0.21 & - \\
$\left(\mathrm{NH}_{4}\right)_{2} \mathrm{SO}_{4}$ & $(5)$ & 3.53 & 0.76 & 0.22 & 0.19 & 0.33 \\
$\left(\mathrm{NH}_{4}\right)_{2} \mathrm{SO}_{4}$ & $(10)$ & 3.76 & 0.84 & 0.20 & 0.19 & 0.37 \\
$\left(\mathrm{NH}_{4}\right)_{2} \mathrm{SO}_{4}$ & $(20)$ & 3.90 & 0.85 & 0.17 & 0.17 & 0.40
\end{tabular}

In the greenhouse experiment, all the $\mathrm{N}$-additions significantly increased the growth of the seedlings but with no significant differences between them except for $\left(\mathrm{NH}_{4}\right)_{2} \mathrm{SO}_{4}$ at the highest concentration, which led to the highest growth (figure 2). Consequently, there was no special effect on growth of the treatments with $\mathrm{NH}_{4} \mathrm{NO}_{3}$ and the additions of $\left(\mathrm{NH}_{4}\right)_{2} \mathrm{SO}_{4}$ did not induce any symptom of toxicity in the seedlings, in contrast to the behaviour of in vitro seedlings.

In relation to the mineral composition of the greenhouse seedlings (table 2 ) the different treatments caused no significant changes in the contents of nutrients, other than a slight increase of $\mathrm{N}$ in the treatments with $\mathrm{N}-\mathrm{NH}_{4}$ especially $\left(\mathrm{NH}_{4}\right)_{2} \mathrm{SO}_{4}$ at highest concentration. There was no accumulation of $S$ in this case. Again, this was in contrast to behaviour under in vitro conditions.

Table 2. Influence of $\mathbf{N}$ on the level of the affected nutrients of olive seedlings in the greenhouse.

Content of nutrient (\% DW)

\begin{tabular}{lccccc}
\cline { 2 - 5 } Treatment & $\mathrm{N}$ & $\mathrm{K}$ & $\mathrm{Ca}$ & $\mathrm{Mg}$ & $\mathrm{S}$ \\
\hline Control & 1.81 & 0.84 & 0.69 & 0.09 & 0.12 \\
KNO3 & 1.95 & 1.01 & 0.62 & 0.10 & 0.13 \\
KNO3 & 1.89 & 0.93 & 0.61 & 0.10 & 0.13 \\
KNO3 & 1.94 & 0.98 & 0.71 & 0.11 & 0.16 \\
NH4NO3 & 2.20 & 0.96 & 0.62 & 0.11 & 0.13 \\
NH4NO3 & 1.99 & 0.98 & 0.50 & 0.07 & 0.10 \\
NH4NO3 & 2.37 & 0.95 & 0.80 & 0.18 & 0.15 \\
(NH4)2SO4 & 2.08 & 0.95 & 0.72 & 0.11 & 0.12 \\
(NH4)2SO4 & 2.14 & 1.06 & 0.61 & 0.08 & 0.14 \\
(NH4)2SO4 & 2.73 & 1.00 & 0.75 & 0.19 & 0.16 \\
\hline
\end{tabular}


In order to partially study the different behaviour of the seedlings cultured in vitro or in greenhouse conditions the evolution of the concentrations of $\mathrm{N}-\mathrm{NH}_{4}$ (figure 3 ) and $\mathrm{N}-\mathrm{NO}_{3}$ (figure 4) of the nutritive solutions in the containers was studied.

Although they do not appear in the figures, the nutritive solutions without $\mathrm{N}-\mathrm{NH}_{4}$ (basal and $\mathrm{KNO}_{3}$ ) did not change their original concentrations of $\mathrm{N}-\mathrm{NO}_{3}$ and $\mathrm{N}-\mathrm{NH}_{4}$ did not appear. The solutions with $\mathrm{N}-\mathrm{NH}_{4}\left(\mathrm{NH}_{4} \mathrm{NO}_{3}\right.$ and $\left.\left(\mathrm{NH}_{4}\right)_{2} \mathrm{SO}_{4}\right)$ clearly changed the $\mathrm{NO}_{3}-\mathrm{NH}_{4}$ equilibriur?. At different levels, depending on the initial concentration of the salt, there was a clear tendency for the concentration of $\mathrm{N}-\mathrm{NH}_{4}$ to decrease and for the concentration of $\mathrm{N}-\mathrm{NO}_{3}$ to increase. In consequence, even when the containers were protected from light, oxidation (nitrification) occurred from $\mathrm{N}-\mathrm{NH}_{4}$ to $\mathrm{N}-\mathrm{NO}_{3}$ and the seedlings did not receive the foreseeable concentration of $\mathrm{NO}_{3}-\mathrm{NH}_{4}$. It was interesting to note that the group of seedlings with the highest growth (those treated with $\left(\mathrm{NH}_{4}\right)_{2} \mathrm{SO}_{4}$ at the highest concentration) received the highest amount of $\mathrm{N}-\mathrm{NH}_{4}$ and this was in accordance with the behaviour of the in vitro seedlings (figure 1). It seemed, in consequence, that there was an important $\mathrm{N}-\mathrm{NH}_{4}$ effect on the growth of olive seedlings.

\section{Acknowledgements}

The work is supported by CICYT. Spain. Project AGR89-0378-C06, "Mejora varietal del olivo".

\section{References}

Bartolini, G., Valentini, A., and Troncoso, A., 1984. Ecceso e carenza di azoto in giovani piante di olivo allevate in idroponica. Ort. Ital. 68:169-180.

Bremmer, J.M., and Keeney, D.R., 1966. Determination and isotope ratio analysis of different forms of nitrogen in soils. Soil Sci. Soc. Am. Proc. 30:577-582.

Campbell, W.H., 1988. Nitrate reductase and its role in nitrate assimilation in plants. Physiol. Plant. 74:214-219.

García-Berenguer, A., 1991. Respuestas morfogenéticas in vitro de la especie Olea europea L. en relación con el estado fisiológico del material vegetal empleado. Tesis Doctoral, Univ. Córdoba. Spain.

Hackett, W.P., 1985. Juvenility, Maturation and Rejuvenation in Woody Plants. Hortic. Reviews 7:109-156.

Hagin, J., Olsen, S.R., and Shaviv, A., 1990. Review of interaction of ammonium-nitrate and potassium nutrition of crops. J. Plant. Nutr. 13:1211-1226.

Keeney, D.R., and Nelson, D.W., 1982. Nitrogen-Inorganic forms. In: Methods of Soil Analysis, Part 2. Chemical and Microbiological Properties. Agronomy Monograph no. 9 (2nd Edition). Amer. Soc. Agron.

Pinta and C.I.I.M., 1973. Méthodes de référence pour la dètermination des éléments minéraux dans les végétaux. Oléagineaux 24:497-504.

Rugini, E., 1984. In vitro propagation of some olive (Olea europea sativa L.) cultivars with different root-ability and medium development using analytical data from developing shoots and embryos. Sci. Hort. 24:123-134.

Sarmiento, R., Villegas, A., Mazuelos., C., García, J.L., and Troncoso, A., 1992. Influence of the $\mathbf{N}$ source and concentration on $\mathrm{N}$-fractions and free amino acid levels of grape vine explants. Plant and Soil 144:255-258.

Sotomayor, E., and Caballero, J.M., 1989. Cracking olive stones withouth damaging theirs seeds. 1 Symp. on Olive Growing. Córdoba. Spain.

Stewart, G.R., and Rhodes, D., 1977. Control of enzyme levels in the regulation of nitrogen assimilation. In: Regulation of Enzyme Synthesis and Activity in Higher Plants. H. Smith (Ed.). Academic Press. London. 1-22.

Troncoso, A., Cerdá., A., and Bartolini, G., 1986. Acción del nitrógeno sobre el desarrollo y la composición mineral de plantas de olivo. Olea 16-17:161-163. 
Troncoso, A., Villegas, A., Mazuelos, C., and Cantos, M., 1990. Growth and mineral composition of grape-vine rootstock cultured in vitro with different levels of ammonium nitrate. In: Plant Nutrition, Physiology and Applications. M.L. Van Beusichem (Ed.). Kluwer Academic Publishers. The Netherlands. 653-654.

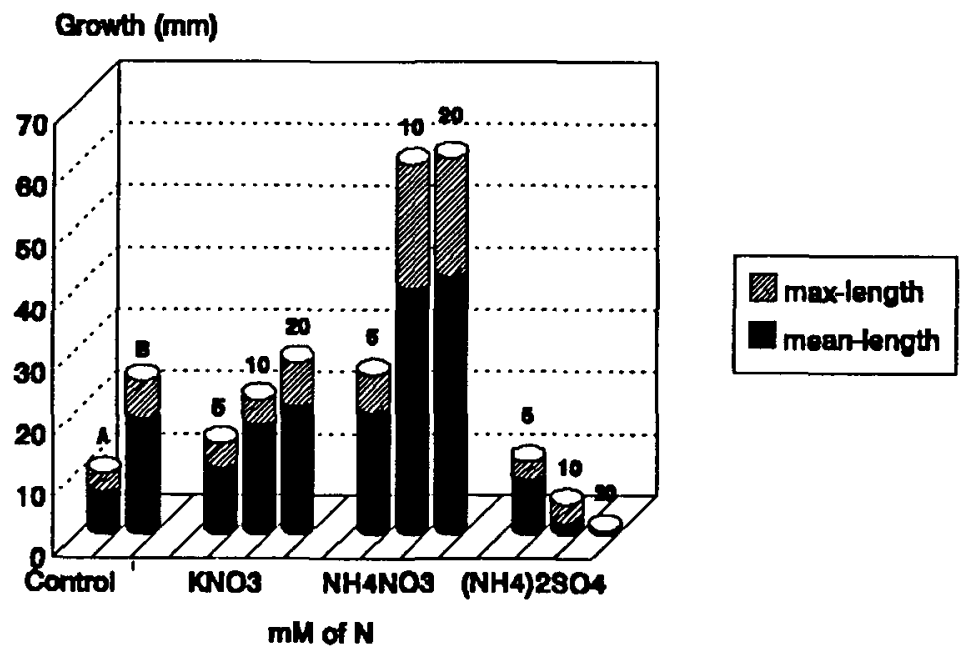

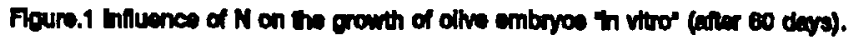

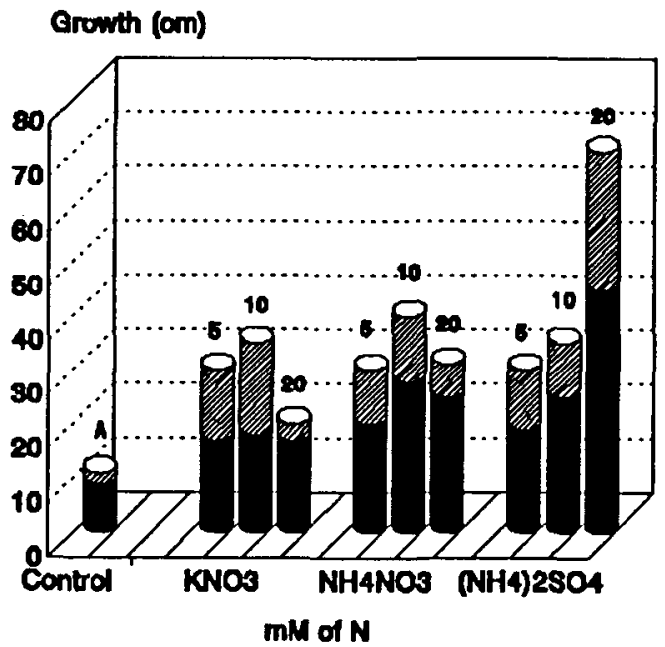

崅 max-longth

mean-length

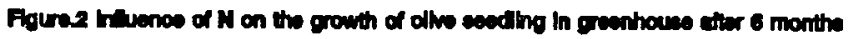




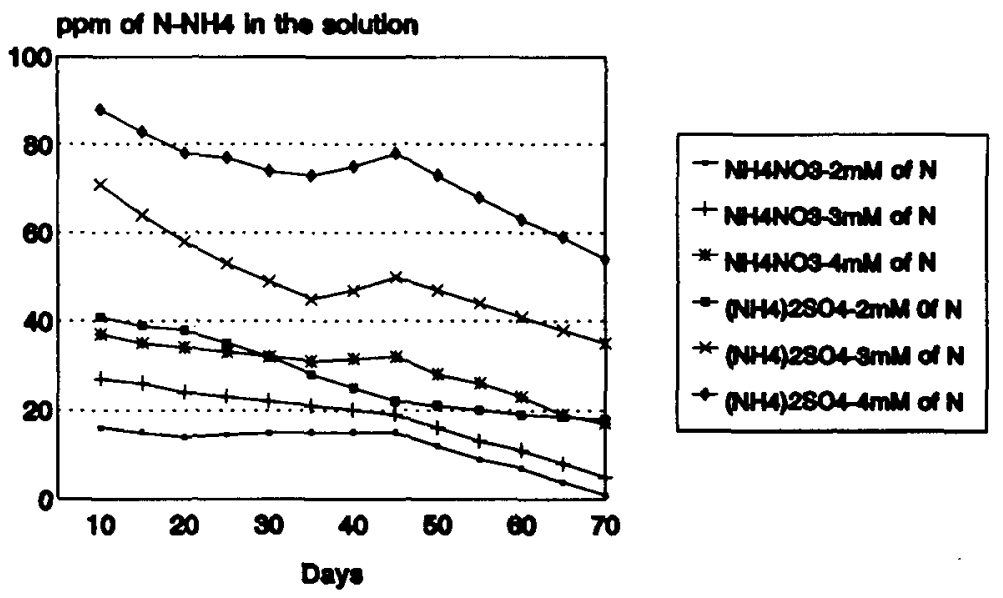

Figure 3- Evolution of the concentretion of NNHA In the nutrtive solutions in the contalnere

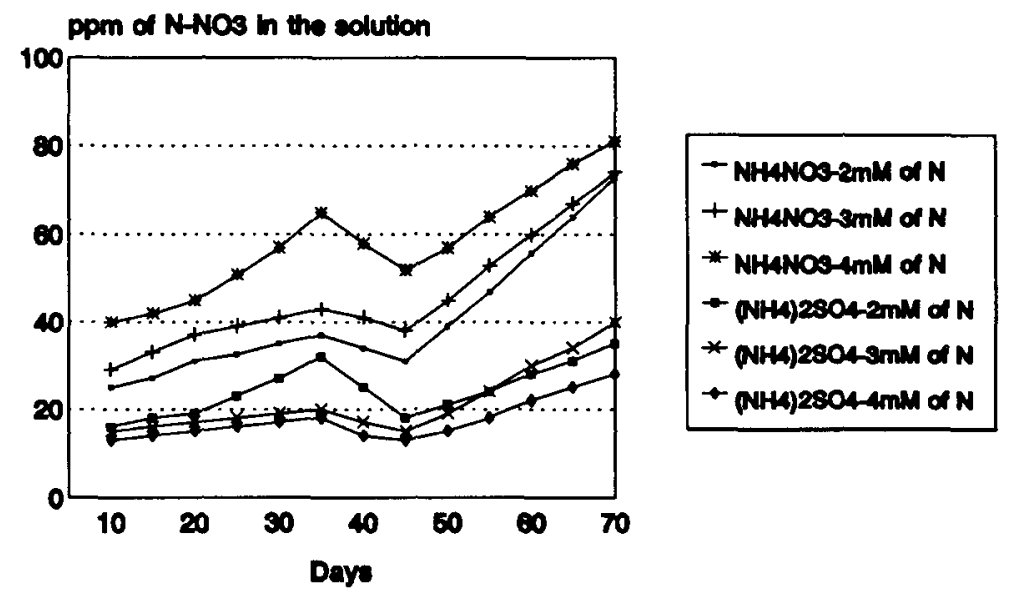

Floure 4 Evolution of the concentratton of N-NO3 In the nututive solutions in the containers 